\title{
Improvement of Green Procurement Performance in the Global Supply Chain: Evidence from Enterprise Resource Planning and Social Network Analysis
}

\author{
Muhammad Shabir Shaharudin 1, , Syafiqa Suhaimi' , Yudi Fernando ${ }^{1}$, Wan Ahmad Fauzi Wan Husain ${ }^{1}$, and Suparman² \\ ${ }^{1}$ Faculty of Industrial Management, Universiti Malaysia Pahang, 26300 Pahang, Malaysia. \\ ${ }^{2}$ Sekolah Tinggi Agama Islam Masjid Syuhada, Yogyakarta, Indonesia.
}

ABSTRACT - The purpose of this paper is to present a plan on how to improve the operational efficiency of the company during the Covid-19 period. Previous research has been reviewed in order to gain further knowledge of the problem; primarily on the operational performance, as well as on the supply chain management of the company. The results have shown that, on the basis of a social network analysis, the Procurement Engineer is the most influential individual in the management of information within the organization, where the Procurement Engineer is also the employee who has a strong link with the transfer of data to top management, the Ishikawa diagram indicates that the present environment is the primary cause of the company's problems in finding products, while the Tree diagram shows the only approach to the issue of insufficient employees is by supplying training for new or existing workers or by assigning staff from another department to serve permanently in a department where there is a lack of staff. In addition, the Enterprise Resource Planning (ERP) framework will strengthen the green supply chain management of the business as it will help to reduce the loss of time waiting for or processing the company's materials, thereby reducing the cost as well. This research offers proof of the pre-Covid 19 and post-Covid 19 impacts on green supply chain operational performance.
ARTICLE HISTORY

Received: $22-12-2020$

Revised: 5-1-2021

Accepted: 1-3-2021

\section{KEYWORDS}

Supply Chain

Performance;

Root cause analysis;

Enterprise Resource

Planning;

Social network analysis.

\section{INTRODUCTION}

The unexpected outbreak in Wuhan, China extended to more than 200 countries worldwide in December 2019. The disease was described by the World Health Organisation as a pandemic (WHO, 2019). Many of the country in the world has declared a lockdown to prevent the spread of the virus. As a result, the large negative effects on society as a whole have also had an impact on many of the company's supply chain management, as they need to re-investigate a better strategy for the company's operational process to increase production quality during the pandemic and improve their green supply chain operating performance.

Green supply chain operating performance refers to the capacity of the company to minimise operating costs, arrange time, lead time, increase the feasibility of the use of raw materials and limit on conveyance (Heizer \& Render, 2013). While in quality service, the success operational performance involves five things, customer satisfaction, employee satisfaction, response to customer concerns and clarification of productivity goals (Khan et al.,2019). Whereas, according to Modgil and Sharma (2016) and Marodin and Frank (2019), costs, efficiency, minimised defects, distribution, innovation, the least possible work in progress and capacity utilisation are the central and most frequently listed dimensions of operational success in manufacturing organisations. Corporate culture is associated with market outcomes, including operating performance, risk-taking, earnings management, executive compensation design and firm value (Li et al., 2020). While in organizational culture is considered a guideline for all of the organization's operations, where organisational culture represents the organization's priorities, vision, mission and growth plans (Kwarteng \& Aveh, 2018). The culture of the organisations may therefore establish a situation that would have an effect on the operational efficiency of the organisation (Saxena \& Kumar Sharma, 2016). Good operational performance will improve the company's operating process and is also an important subject in terms of competition with other companies. That is why operating performance in the study is significant.

In Malaysia, there are many industry that had been implement a supply chain in their company, but the operating performance are still low. For example, from the previvous researcher Saudi et al. (2019) had stated in their research that, Malaysia's electronics industry has lower performance compared to other countries such as Australia, Brazil, Canada, Hong Kong, Indonesia, India, Israel and Japan, as can be seen from the world electronics industry report. Malaysia's electronics industry therefore needs to focus on a variety of supply chain activities to boost overall performance. A study on Malaysian textile and apparel companies revealed that "relative capacity" that includes supplier collaboration, customer relationship, information sharing and information quality, and "organisational culture capacity" that includes 
organisational participation, consistency, adaptability and creativity are critical success factors in strengthening the operational supply chain; They should therefore pay more attention to the relational capacity and organisational culture capacity to improve the operational performance of the supply chain (Loon et al., 2019). Asyraf (2020) has in his study, had a range of managerial consequences for the company's managers for the improvement of operational performance. Four factors have been identified that will lead to operational success in Malaysia's customer-focused industry, top management support, process control and enhancement and, lastly, supplier management. Furthermore in his research also stated that the management of companies in Malaysia should concentrate on other supply chain management strategies that could improve customer focus, top management support and the management of the company's suppliers.

However, Malaysian companies are also met with no exception to the implications of the announcement of the Movement Control Order (MCO) during the COVID-19 pandemic and the effect of post-locking or MCO on some businesses was to reorganise their management in order to respond to the current pandemic situation. The research objective of this study is to evaluate the performance of green supply chain operational performance of HHA procurement, to determine the effect of the Covid-19 pandemic on green supply chain operational performance of HHA procurement, and to assess the progress of HHA procurement green supply chain operational performance based on the ERP framework. The introduction of this company is due to its strong known factor, which is the organisational culture capacity. In order to strengthen understanding of the problem statement, a research process has been to accommodate this research. It focuses primarily on understanding and improving organisational efficiency and operational performance. In addition, an interview and survey were performed with the company representative in order to collect data for the purpose of production. The results of this paper will be carried out using an analytical approach by analysing all the information received. The approach to be used is the Root Cause Analysis to identify the main cause of the problem in the company and the Social Network Analysis to identify the connection of each community in the company.

\section{LITERATURE REVIEW}

\section{IMPACT OF COVID-19}

The situation of the pandemic dramatically increases carbon emissions and environmental degradation, while at the same time posing major challenges to the social and economic viability of business activities (Kumar et al., 2020). The COVID-19 pandemic triggered a significant economic breakdown around the world as consumer demand and business activity and trust plummeted. Business activity around the euro area plummeted to a record low in March 2020, with US industrial productions recording the largest monthly fall since the end of the Second World War (Badkar \& Greeley, 2020). Significantly, as Fabeil et al. (2020) pointed out in their study, As the crisis has grown unforeseen, affecting not just the whole organization, but also entire segments of the economy, the Covid-19 crisis can visibly be seen as a 'Sudden Threat'. The influence of the Covid-19 pandemic on the global socio-economy will be serious, and recovery for survival will be crucial for a modern, normal way of life (Fabeil et al., 2020).

Many nations ban the movement of their residents and close their economic practices and big events, including schooling, to avoid the spread of the disease (Toda, 2020). Several nations, including Southeast Asian countries such as Indonesia, Malaysia, Thailand, the Philippines and Singapore, have imposed travel restrictions, social distances and postponement of activities for at least 14 days in their respective countries for the Covid-19 epidemic.(Fabeil et al., 2020). Not only have emergency or quarantine directives to prevent coronavirus transmission in many countries contributed to psychological consequences such as depression, anxiety and stress (Ghani, 2020), but industrial practices have also had an impact, such as the shutdown of store premises and the disruption of food supply chains (Karabag, 2020). For example, from a COVID-19 pandemic prevention perspective in China, quarantine policies have effectively stopped the pandemic from spreading through the world. Around the same time, though, supply and demand have weakened, leading in the first quarter to a stagnating economy and decreasing corporate efficiency (Shen et al., 2020).

On 24 January 2020, the very first case of COVID-19 in Malaysia was recorded, involving three tourists from China who entered Malaysia via Johor. Malaysia then reported the first sporadic case of Covid-19 among the population on 11 March (Abdullah et al., 2020). In Figure 1 and Figure 2, the cases of Covid-19 in Malaysia are shown.

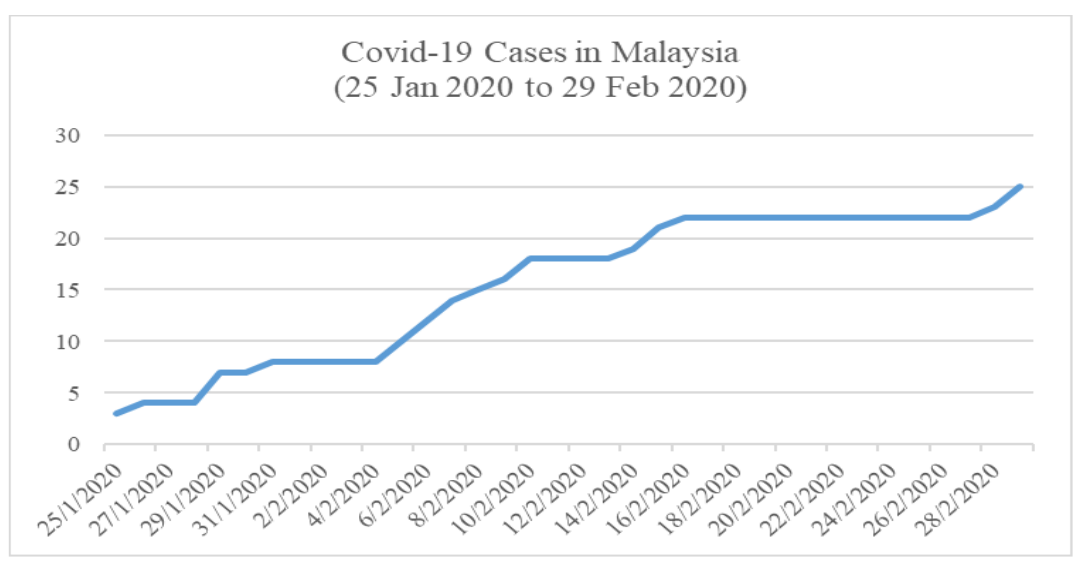

Figure 1: Covid-19 reports in Malaysia between 25 January 2020 to 29 February 2020. (WHO,2020) 
Figure 1 shows that the cases of Covid-19 in Malaysia started after the end of January and began to increase rapidly since then but managed to stabilise the number of cases for more than a week until they started to increase again until the end of February.

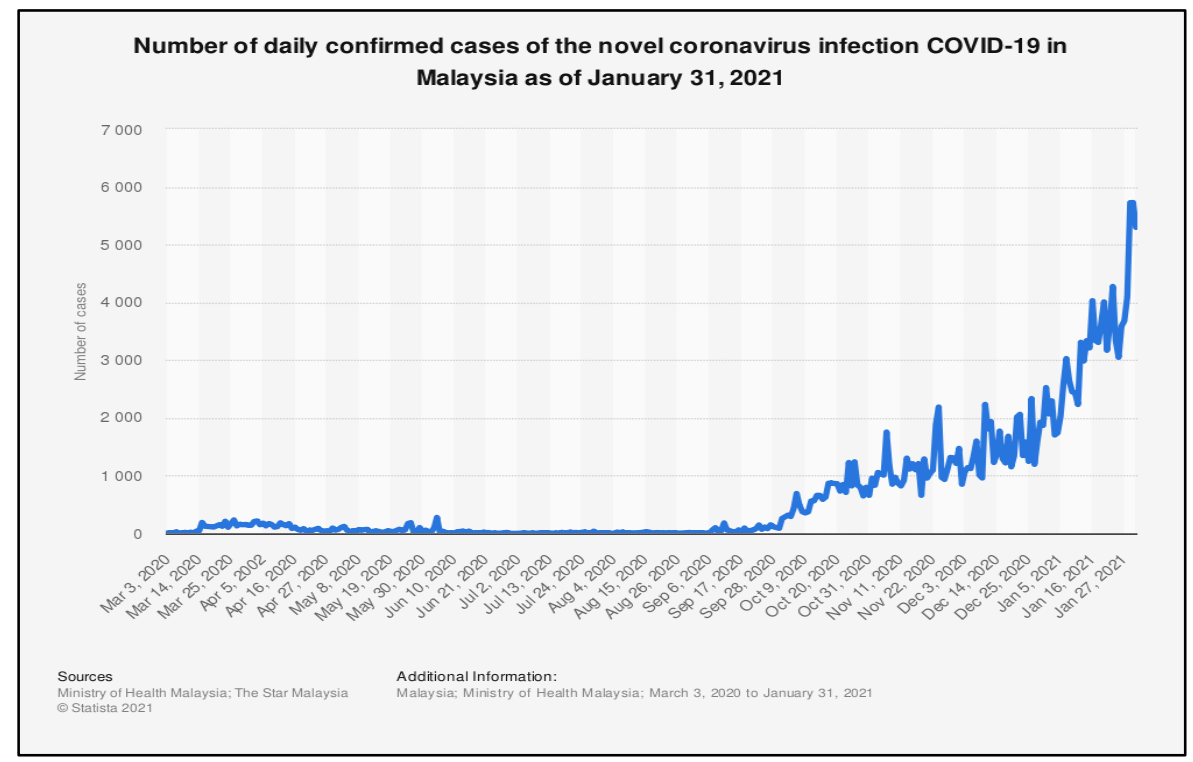

Figure 2: Covid-19 cases in Malaysia from March 2020 until January 2021 (Statista,2021)

When Malaysia had only started breathing relief after the cases had cooled to zero for a few days after the beginning of March, the cases unexpectedly spiked continuously during the second week of March and ended up with the government's announcement of the Movement Control Order (MCO).

Malaysian companies are also met with no exception to the implications of the announcement of the Movement Control Order (MCO) during the COVID-19 pandemic. The MCO has been phased out and each process has its own relaxation, as only one or two individuals are permitted in the vehicle.A proposal was then revealed on 1 May to ease the lockdown by enabling businesses to open on 4 May.

The government's plan to conduct the MCO in Malaysia for approximately 3 months (March until May) had a positive impact on reducing daily cases, and during July until early September, Malaysia even reported 0 cases a day for a few days. However, due to the incompetence of some parties in dealing with these problems, the daily Covid-19 cases in Malaysia are currently spiking up to more than 4000 cases a day.

The COVID-19 pandemic and economic recession have had a negative impact on various industries, including tourism, retail, aviation, construction and travel (Nor et al., 2020). In line with the findings of Shen et al. (2020) that the pandemic of COVID-19 ended in a downturn in industrial outcomes, both in business and in the field.

In addition to the significant economic breakdown of the pandemic, certain companies still have an increasing appetite during the pandemic. The demand for unusual manufacturing items, such as ventilators, gloves, face shields, masks and sanitizers, is strong (Kumar et al., 2020). In order to deter the transmission of the virus, government SOPs and precautionary steps must be implemented, such as wearing a face mask, body temperature screens, social isolation and hygiene (Voon, 2020).

\section{THE IMPACT OF LOCKDOWN TO THE COMPANY}

The impact of a conflict or disaster on a company should be of great concern to businesses as it influences present and future business performance (Fabeil et al., 2020) as the company was unable to function as usual until the pandemic occurred (Macfarlane, 2020). The post-pandemic development system needs awareness of social distances at the workplace and daily health monitoring of the workers (Kumar et al., 2020).

Organizations should concentrate on the well-being of the workforce, mental wellbeing and health monitoring activities. Regular temperature scanning and regular health check-up minimise the effect of COVID-19 on implant operations. Information control of social distances, personal hygiene and the use of masks at the site decreases the effect of COVID (Kumar et al., 2020).

Apart from being a compliance mechanism, it is up to companies themselves to understand that an outbreak inside their facilities will be expensive if staff or consumers contracted the virus (Voon, 2020). Financial restrictions can make the pandemic activity even more difficult (COVID-19) (Shen et al., 2020).

\section{GREEN SUPPLY CHAIN OPERATIONAL PERFORMANCE}

Supply Chain Management (SCM) can be defined as governing the flow of information, products, resources, capital equipment, staff, etc. to the interactive network of suppliers, service providers, OEMs, customers and other stakeholders in the supply chain (Farsi et al., 2020). The ultimate aim of the supply chain is to distribute products effectively and 
customer services in minimum time, minimum overall cost and higher quality (Naway \& Rahmat, 2019). As all Supply Chain Partners add value to goods and services, the sustainability of the focal company cannot be achieved unless all Supply Chain Partners are in harmony with the environment and society (Kumar et al., 2018).

However in order to improve their ability to respond rapidly and cost-effectively, supply chains must adopt new strategies for unpredictable market changes and increasing levels of environmental turbulence, both in terms of volume and variety (Alzoubi \& Yanamandra, 2020).

Green Supply Chain Operational Performance Management (GSCOP) has become a major focus for businesses to lead the way for competitiveness. A variety of performance evaluation and analysis approaches have been developed in recent decades to evaluate the performance of the supply chain from different perspectives (Ramezankhani et al., 2018). Few studies have highlighted that GSCOP has five main performance attributes, including reliability by reference to distribution and order fulfillment, responsiveness by reference to speed, turnaround time and order fulfillment, agility by reference to versatility in market reaction, cost containment by reference to production costs, warranty costs and processing costs of return and, finally, asset management by reference to inventory, return on fixed assets and operating costs (Naway \& Rahmat, 2019; Adivar, et al. 2019).

\section{COST REDUCTION}

Supply Chain Finance has long been recognised as a major intersection of trade finance and supply chain management. As a consequence, providing funding for trading along the supply chain is becoming a fundamental business for banks, producing real value for both manufacturers and buyers, who need not only timely production and delivery of goods, but also well-structured Supply Chain Finance solutions to free up more cash at a reasonable financial cost (Wang et al., 2020).

In addition, SCF has been identified to minimise operating costs and produce income for upstream/downstream players in the supply chain (Brick and Fung, 1984; Dye and Yang, 2015; Gong et al., 2018), boost financial efficiency of companies (Caniato et al., 2016) and encourage the sustainability of the supply chain.

\section{FLEXIBILITY}

Over the last two decades, a great deal of study has gone into describing the various forms of versatility or the different forms of flexibility or adaptability in production, but there is still no widely accepted definition of flexibility (Muntaka et al., 2017). Subsequently, this view was echoed by Upton (1994), who considered flexibility to be the product of the various elements, each of which appears in different periods of time and with three typically unmistakable 'components' or methods of flexibility: range, mobility and uniformity.

However both studies by Farsi et al. (2020) and Ivanov et al. (2018) reported that flexibility refers to the ability of processes to adjust the supply chain to changes in customer demand.

\section{RESPONSIVENESS}

Responsiveness to the supply chain is a constant stream of data, and the commodity supply chain stream must be in the right position at the right time (Javaid \& Siddiqui, 2018). It is defined as the speed of the supply chain; the provision of products, services or information to members of the supply chain. In addition, the cost of the supply chain is defined as the cost of running the supply chain (Naway \& Rahmat, 2019).Based on research in the fashion industry, Choi and Guo (2017) has shown that customer returns will increase the value of fast response to the producer. They also show that more responsive supplies will reduce environmental costs.

Furthermore,the most important output outcome in the supply chain, which is expected from improved interorganizational partnerships, is a time reduction period. Prompt competition-based reforms placed more pressure on businesses' time-based ability to capture the benefits of a flexible approach to changing economic circumstances. Responsiveness may be affected by the type of product, the type of market, and the dynamics of market forces. The reaction of the business is measured on the basis of the flexibility and distribution time of the product (Javaid \& Siddiqui, 2018).

\section{ENVIRONMENTAL FRIENDLINESS}

Within the reach of green practises, any phase of movement of materials and knowledge needs to be carried out within the context of environmental requirements (Naway \& Rahmat, 2019).

Traditional methods, which set targets for the supply chain, merely consider economic factors such as cost reduction, time reduction, timely delivery of goods, etc. (Jiang et al., 2017). In comparison to conventional approaches, consumer demands have evolved in such a way that the company's environmental and social performance has now become as relevant as its economic performance from the point of view of its consumers. Governments and administrations all over the world pay attention to calls not to sacrifice the quality of life for the exploitation of natural resources and the pollution of the air (Ramezankhani et al., 2018).

A recent study by Paulraj et al. (2017) found that green logistics management increases operational efficiency, eliminates waste, conserves energy and meets societal standards for environmental protection. The benefits of environmentally friendly activities in the supply chain are minimal (Evangelista et al., 2017) and the cost-effectiveness factor is the first reason for logistics firms to implement green supply chain practises (Centobelli et al., 2017).

Furthermore, Fang and Zhang (2018) find that externally and internally GSCM operations are related to firm perforation, and both are highly related. They find that both operational and economic efficiency were found to be 
related to the environmental performance of GSCM activities and that there is also a clear significant correlation between technical and financial performance.

\section{THEORY OF SOCIAL NETWORK}

The study of the social network is a valuable tool to analyse how and why actors cooperate through their connections to each other and through analysing the organisational patterns of those connections within a community. Social networks also represent whether cooperative activity between actors is organised in a way that best enables or suits the context to achieve governance objectives sufficiently (Partelow \& Nelson, 2020).

The social network theory focuses on the interaction between actors to describe the results of the actor and the network (Froehlich et al., 2020). The theories of collective action can explain the social and ecological conditions that affect the emergence of self-organization and social networks (Partelow \& Nelson, 2020).

One of the ways used to measure the study of the social network is to describe the centrality of the corporate social network. Based on the studies performed by Camacho et al. (2020), they observed that centrality is used to determine the importance or systemic value of a network node. This determines the value of a node in a network. On the other work done by De Nooy et al. (2018),there are three centralities of the social network, namely degree centrality, betweenness centrality and centrality of closeness proximity. The first and simplest measure is the degree centrality (DC), which counts the number of neighbours the node has in the network (i.e. the number of connections the node has). Indegree and outdegree centrality are used with a direct relationship. While the Betweenness centrality (BC) is used to calculate the centrality of a network based on the shortest path theory. widely used property to identify important nodes in social networks (Nakajima \& Shudo, 2020).Lastly,for the closeness centrality, the node is said to be closest to other nodes if its presence is closest to that network. In other words, it also refers to the shortest path between the nodes deployed. As a result, the nearest nodes have the highest visibility in the network

Linking social network analysis and collective action research is a promising way to better understand how collaboration is organised and how it reacts to change (Partelow \& Nelson, 2020). The essence of SNA in discussions on quantitative, qualitative and mixed methodologies is unclear. Most researchers consider SNA to be a systematic or quantitative technique (Crossley \& Edwards, 2016; Hollstein, 2014).

\section{ENTERPRISE RESOURCE PLANNING(ERP)}

The Enterprise Resource Planning also known as ERP program are well known in the business sector due to its ability to store and distribute data within the organization. Based on the Jafari and Nair (2018) report, they stated that during this modern era, different businesses have applied the ERP software through the software and structure of their own organization and since there are so many trends in the company, the ERP systems have become the competitive market environment.

Furthermore, different modules are included in the Enterprise Resource Planning (ERP) software that helps the company manage the management of the company from different departments. The modules are shown in the Figure 3.

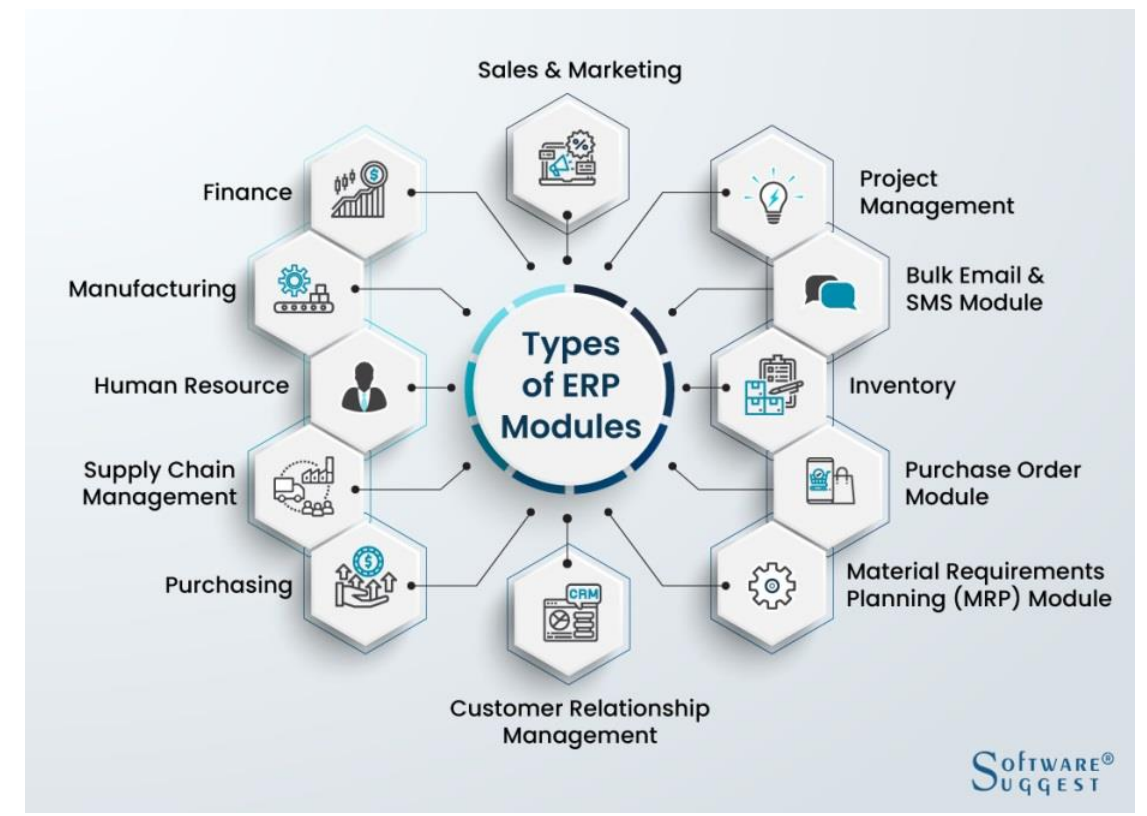

Figure 3. Types of ERP Modules (Parmar.,2019)

Figure 3 shows the modules that could be used in the ERP system. As seen in Figure 3, Enterprise Resource Planning could be included in an organization's particular form of department that helps to handle the matter of the company. For example, the people from the project management department could track the details from the sales and marketing department in real time using the Enterprise Resource Planning (ERP) software. With this support, the company's 
management advantage in any of the divisions may be given. It would also increase the accountability, operational effectiveness and data-driven decision-making of the business.

In fact, there are many types of ERP applications that can be applied in the organization, such as Cloud ERP and OnPremise ERP. The disparity between the two models (Cloud ERP and Traditional ERP) shown in the analysis by Hussein et al. (2019), can be seen in the Table 1 .

Table 1. Comparison between Cloud ERP and Traditional ERP

\begin{tabular}{|c|c|c|}
\hline $\begin{array}{l}\text { Categories of } \\
\text { differences }\end{array}$ & SaaS-ERP (Cloud ERP) & $\begin{array}{l}\text { On-Premises-ERP } \\
\text { (Traditional ERP) }\end{array}$ \\
\hline $\begin{array}{l}\text { Selection of } \\
\text { modules }\end{array}$ & $\begin{array}{l}\text {-Packages should be subscribed to the } \\
\text { product modules in such a way that they } \\
\text { can not subscribe to a specific package } \\
\text { only, which limits the versatility of option. }\end{array}$ & -Only the modules needed will be purchased \\
\hline Updated & -Included in the subscription fees & $\begin{array}{l}\text {-Included in maintenance fees, but additional } \\
\text { charges for updating hardware and software are } \\
\text { required. }\end{array}$ \\
\hline $\begin{array}{l}\text { Implementation } \\
\text { time }\end{array}$ & -Short & -No fast deployment \\
\hline Mobility & -Accessed from anywhere & $\begin{array}{l}\text {-Accessed from the location of ERP system } \\
\text { servers via the web, but special packages must } \\
\text { be purchased, resulting in additional costs. }\end{array}$ \\
\hline $\begin{array}{l}\text { Cost of ERP } \\
\text { Installation }\end{array}$ & $\begin{array}{l}\text {-No maintenance costs as the device are } \\
\text { already installed on the server provider. }\end{array}$ & -Set up cost and systems installation cost \\
\hline $\begin{array}{l}\text { Flexibility in } \\
\text { the ERP } \\
\text { modules }\end{array}$ & $\begin{array}{l}\text {-Additional modules can be added in a } \\
\text { short time, if necessary }\end{array}$ & $\begin{array}{l}\text {-New modules that need to be installed to } \\
\text { install a new package from the ERP program } \\
\text { and removed from the old package. }\end{array}$ \\
\hline $\begin{array}{l}\text { ERP system } \\
\text { total cost }\end{array}$ & $\begin{array}{l}\text {-Monthly subscription fee for ERP system } \\
\text {-No maintenance cost }\end{array}$ & $\begin{array}{l}\text {-Cost of license } \\
\text {-Maintenance cost is often annual }\end{array}$ \\
\hline
\end{tabular}

As seen in Table 1, the SaaS-ERP or the Cloud ERP is possibly ideal for an organization that runs the company and has various facilities in different locations around the world or region, as this model's mobility is that it can be accessed from anywhere. While the On-Premise-ERP or the traditional ERP is more appropriate for the company that operates in a single facility, as the model could only be accessed in the place in which the ERP was installed. In terms of the disparity in functionality between the two versions, the Cloud ERP is simpler as the ERP modules can be added in a short time and do not need to take much time to install the module, whereas the Traditional ERP requires to be installed some time as some modules need to be disabled and reinstalled to meet the requirement for new modules.

In each management firm, the expense is the most critical problem in organizing or doing certain operations in the company. As with the deployment of ERP applications, the overall expense of both versions tends to have different values. The organization has to pay the annual subscription fee for the Cloud ERP, and they do not need to pay any servicing costs. In the opposite, the conventional ERP allows the organization to pay only the expense of the execution license and must often pay the cost of servicing yearly. The big company is therefore more likely to implement the Cloud ERP, while the small company is more likely to be able to use the Traditional ERP software.

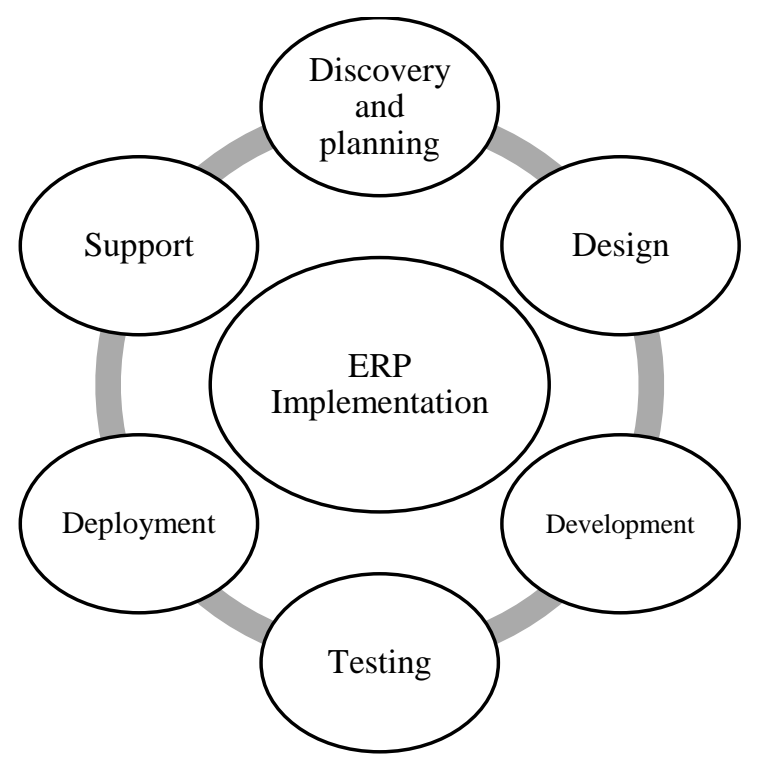

Figure 4. ERP System implementation model/framework diagram 
Figure 4 displays the layout diagram of the Enterprise Resource Planning (ERP) framework. It shows the phrase of work that company would use for their manager systems within the company. This also demonstrates that the structures bind a management to another.

The project team has to collect feedback on numerous business group criteria and problems that the ERP systems need to address in the discovery and preparation process. The team has to evaluate the current workflow in the next step, which is the design process, and customize the program and how to transfer data to the new system. In the development process, the design of the program is included in the performance of company specifications. In order, to transition to the new technologies, the team should create a training content and paperwork for the employee. To continue preparing data transfer, this phase is often important.

To fix any issues that occur, the testing phase is to gradually test the system's functions and fine-tune development. The phase of deployment is when the devices are about to go live and the team has to be prepared for some challenges, as there could be a lot of moving parts (data) and probably some confused workers. Last but not least, the process of support and updates is where the team wants to ensure user satisfaction by using the services and tries to upgrade the systems and repair issues as required.This may be the proof that ERP Systems will help to present data to another department without moving from another department.

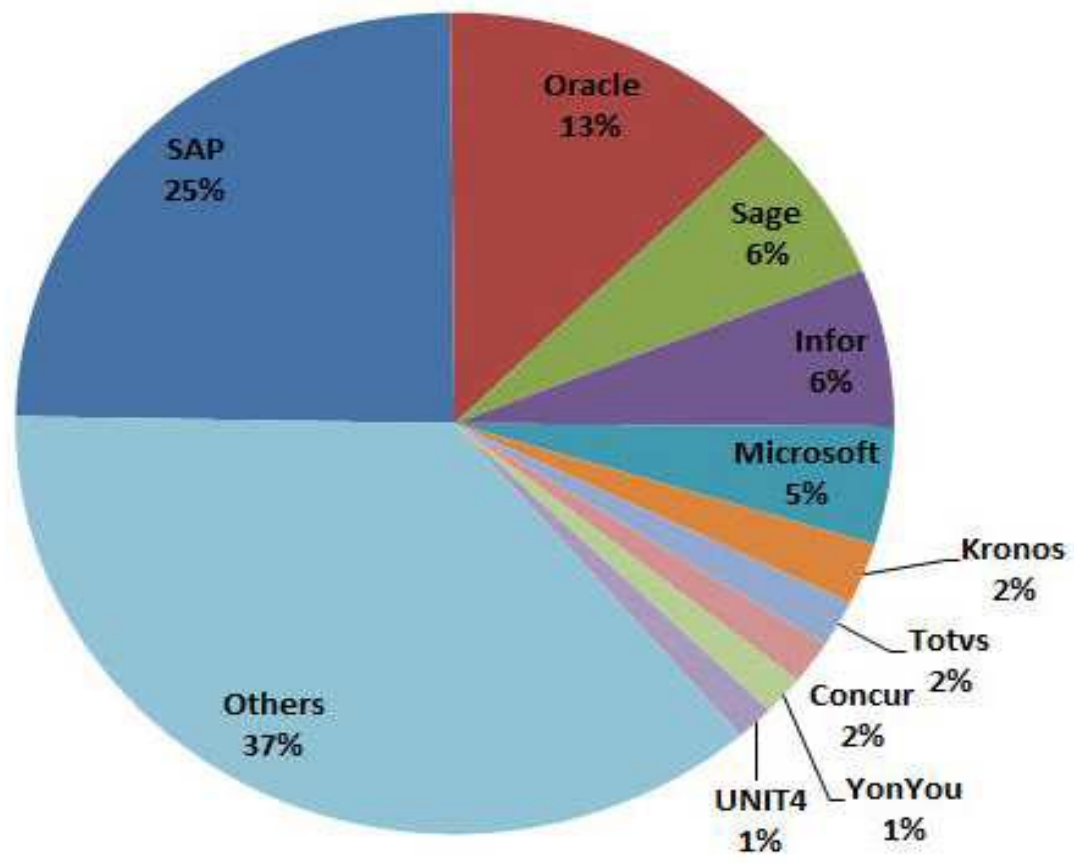

Figure 5. ERP Software Market Share (Jafari \& Nair,2018)

Based on the results of AlMuhayfith and Shaiti (2020), they argued that the efficacy of the schemes is likely to be attributed to the brands of the ERP itself. They used distinct ERP brands such as Oracle, SAP, Delta, Microsoft Dynamic AX, Inbuilt ERP Application, Peole Soft and other ERP brands for their review in their article. As for the market share of ERP brands that was seen in Figure 5, it reveals that SAP is the second largest market share with 25 percent of the ERP brand and 13 percent led by Oracle. Sage and Infor, on the other hand, shred the equivalent market share with 6 percent and the UNIT4 and YonYou with 1 percent are the least market share that has been shown.

Eventually, while the ERP systems give the business such an advantage, the systems can often be a waste of enforcing the device. Menon and Sreekumar (2016) observed that if there is no professional management that runs the systems and no instruction is given in the use of employee systems, introducing the systems is only a waste of resources as the system is too expensive.

\section{THEORETICAL FRAMEWORK}

Theoretical Framework is a structure focused on an established research theory that is connected and/or represents the hypothesis of a study. It is a blueprint that is frequently 'borrowed' by a researcher to create his/her own house or study. It serves as the base on which research is being developed (Adom et al., 2018).

Ravitch and Carl (2016) accept that the theoretical structure would assist researchers in situating and contextualising formal theories in their studies as a reference. They are placing their studies in scholarly and academic fashion. In addition, the theoretical structure acts as a focal point for analysis and is connected to the research topic under review. Its directs the researcher so that he/she does not deviate from the boundaries of established theories in order to make his/her final academic and scholarly contribution (Adom et al., 2018). 
For field scholars and readers, the correct selection and presence of a theoretical framework convinces them that the analysis is not focused on the researcher's personal instincts, but is firmly rooted in the existing theory chosen by reliable studies (Akintoye, 2015).

\section{CASE STUDY OF HHA ASSOCIATES}

HHA Associates Sdn.Bhd is a Petronas Registered Company specializing in production and maintenance services in the oil and gas business. Since its inception in 2003, HHA has been expanding its range of services and expertise to facilitate the rising demands of the industry. HHA services include the provision of process equipment and personnel; engineering, operation and maintenance services; and construction and manufacturing services to support the upstream and also for the downstream sectors of the oil and gas industry.

HHA's head office is located in Teluk Kalong Industrial Area, with the aim of facilitating their manufacturing, inspection, testing and storage services. HHA also operates two different yards in two different locations; Teluk Kalong Yard is the site office for its Top-Side Construction Maintenance Services (TCMS) and Top-Side Blasting Painting Services (TBPS) operations for CAKERAWALA COMPLEX CARIGALI HESS OPERATING COMPANY SDN BHD, while Labuan Yard is a manufacturing yard. They also had a supply base branch based at the Kemaman Supply Base, as well as a main office in Kuala Lumpur.

Due to the Pandemic Covid-19 that occurred in the country, there were a few problems that disrupted the company's operational performance in order to adjust to the situation; more transactions should be made during the pandemic for the health care of employees, more work should be done on the operational process and difficulties in finding good quality with a low price product during the pandemic.

\section{METHODS}

This research was carried out using both a qualitative and a quantitative approach to provide the deepest understanding of the main information that need to be found, that is, the way in which the company's financial performance during the Pandemic Covid-19 has increased and the cause of the company's cost increase. Figure 6 shows the research progress for this paper.

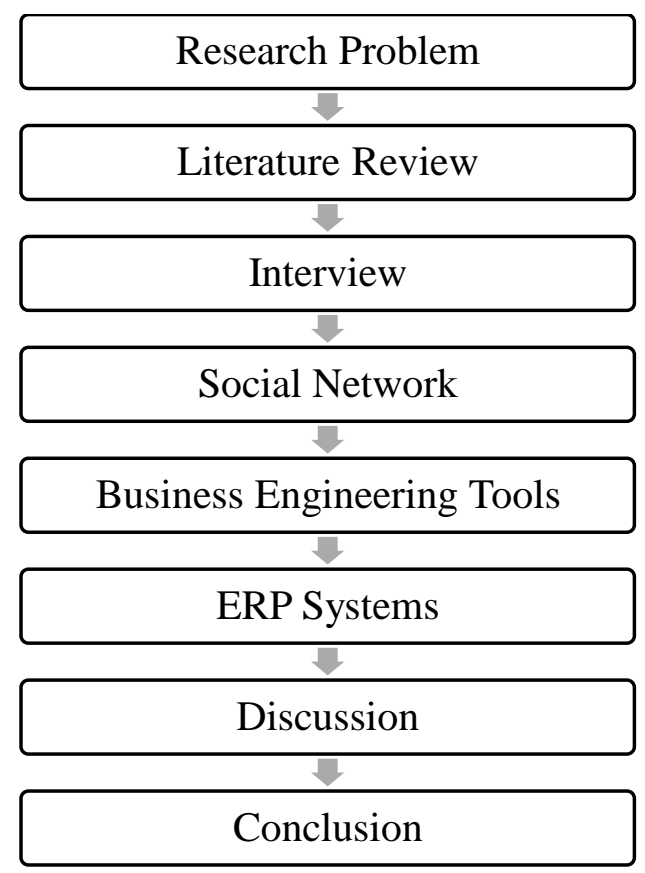

Figure 6: Research Progress

The research issue is a subject that a researcher highlighted in their research to fix. The problem found in the chosen company (HHA Associates Sdn.Bhd) in this study is the company's budgeting issues in seeking raw materials and also their insufficient labor problems. A literature review was carried out after the problem was established to provide more understanding and examine the problems in previous articles or other reading materials on the related topic. Different reading materials were selected to provide more comprehension for this project, and the quest for all the reading material was filtered to narrow the chance of finding. Most of the selected journals have been written from 2018 to the present, as well as several journal references from the 1900s and early 2000s. The Pandemic Covid-19, Social Network, Supply Chain and Enterprise Resource Planning (ERP) are the subjects of the chosen journal.

The interview method tends to be the most encouraged method to be used for the purpose of gathering data. The interview session includes verbal contact between the participant and the researcher, the purpose of which is to gather data (Bhatia, 2018). For the interview process, analysis for interview is transcribing the interview transcript and finding 
a common theme and ANTCONT. But because of time constraints, interviews can only be performed via email and phone calls and all the data had been listed down for analysis purpose. For this paper, 3 employess had been invited to participate in the study. The interviewees' name is Mr. Izaruddin Azizan Bin Bahari is the Procurement Engineer of HHA Associates Sdn.Bhd, Hazzira Binti Hasbullah,the Technical Assistant in the company and also Syafiq Bin Adnan, the Procurement Clerk of the company. The interview via email can be found in the appendix.

If the data collection stage has been completed, a structured means of extracting relevant information from and data should be used (Snyder, 2019). The analysis was therefore carried out in order to analyse the informations from both of the interview and the questionnaire process. The issue of a particular study and the form should be different and it is necessary to ensure that the research question chosen is answered appropriately (Snyder, 2019). At this point, the study of the social network is an effective analysis method to be used for this article. As both researchers Moolenaar (2012) and Sweet (2016) have said, there is no other empirical approach than an in-depth study of learning and instruction relations and structures.At this point, the Social Network Visualizer software was used for the purpose of the Social Network Analysis to classify the social network of the interviewees in the organisation.

After the introduction of the social network, the tools for business engineering are required to solve the problems. An option that incorporates both business and engineering strategies to solve a problem is Business Engineering tool. For instance, the use of engineering tools to solve a business problem. The Enterprise Resource Planning (ERP) frameworks are the methods of Business Engineering chosen and analyzed from previous research to find the potential of helping problems. All the findings from previous phases are next to be discussed and the project is eventually completed.

\section{RESULTS AND DISCUSSION}

After the Movement Control Order (MCO) had declared, a new life standard was implemented to limit the spread of the virus. The new standard of living is different from the normal lifestyle, as everyone needs to comply with the Standard Operating Process (SOP) declared by the government. In order to comply with the SOP, HHA Associates Sdn.Bhd had to make a major transformation not just in the working style, but also in the workplace.

And though the company's sales are effected during the Movement Control Order (MCO) due to lack of a project, they also need to pave the way for the addition of health care costs to their workers. They insisted that the cost would be waived as long as it could benefit the company. During this time, HHA Associates Sdn.Bhd had prepared various health care products such as PPE, hand sanitizer and mask for their employees. In certain cases, the organization may also provide the employee with a swab test if demanded by the client or by the government.

At present, the company also carries the full payment of its workers' allowances without cutting off any extra fees or laying off a number of employees. However, given that the virus is unpredictable and that no cure has yet been identified for this virus, the organization plans to decrease the number of employees in tears by 2021 .

\section{ROOT CAUSE ANALYSIS}

This approach is to determine the the objective research of this paper that is to understanding more about the organisational efficiency and analyzing the main cause of the problem that occurred in the work process of the company. Before the Pandemic Covid-19 had emerged, the supply chain process in the business was to deal with the supplier asking for the commodity to comply with the company's norm. Then after the product has been ordered, the purchasing will be made. Then the product will be sent to the store and eventually delivered to the offshore. Figure 5 below shows the Supply Chain process in HHA Associates Sdn.Bhd.

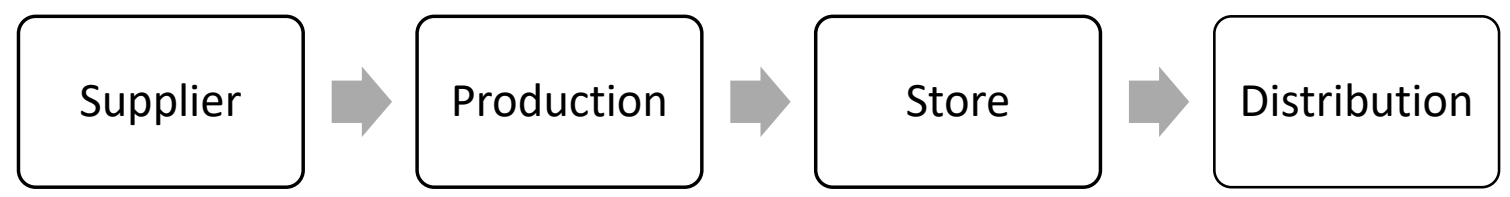

Figure 7: Company’s supply chain process

Figure 7 indicates the department involved in the company's work process. Initially, the company can request and locate an item of reasonable quality at the lowest price. When the item has been found, it will be passed to the manufacturing team to inspect the actual data of the item and the price of the products. After the inspection is carried out the item will be shipped to the store department by the supplier and the item will be registered by the store team at the date of the stock record.Finally the item is given to the logistic department which the team will distribute the item to the operation yard or offshore team to use. To be exact, , HHASB Associates is an oil and gas company that's provide maintenance service \& fabrication to offshore and onshore. However, even when this pandemic happened, this organization had used this supply chain mechanism and this could create an issue with the operation itself and there is inflexibility of adjusting the working atmosphere to accommodate the present situation.

Additionally, since the Pandemic Covid-19 has taken place, the business has to face a problem in finding high quality products at a low price. For example in the case of PPE goods, it is cheaper before the pandemic, but it is becoming costly 
due to the growing demand after the pandemic, and the quantity of the product is also reduced. In addition, the price of the oversea item also increased by 150 percent compared to the normal price. For this problem, an Ishikawa diagram was placed in place to describe the root cause of the problem in the hunt for products.

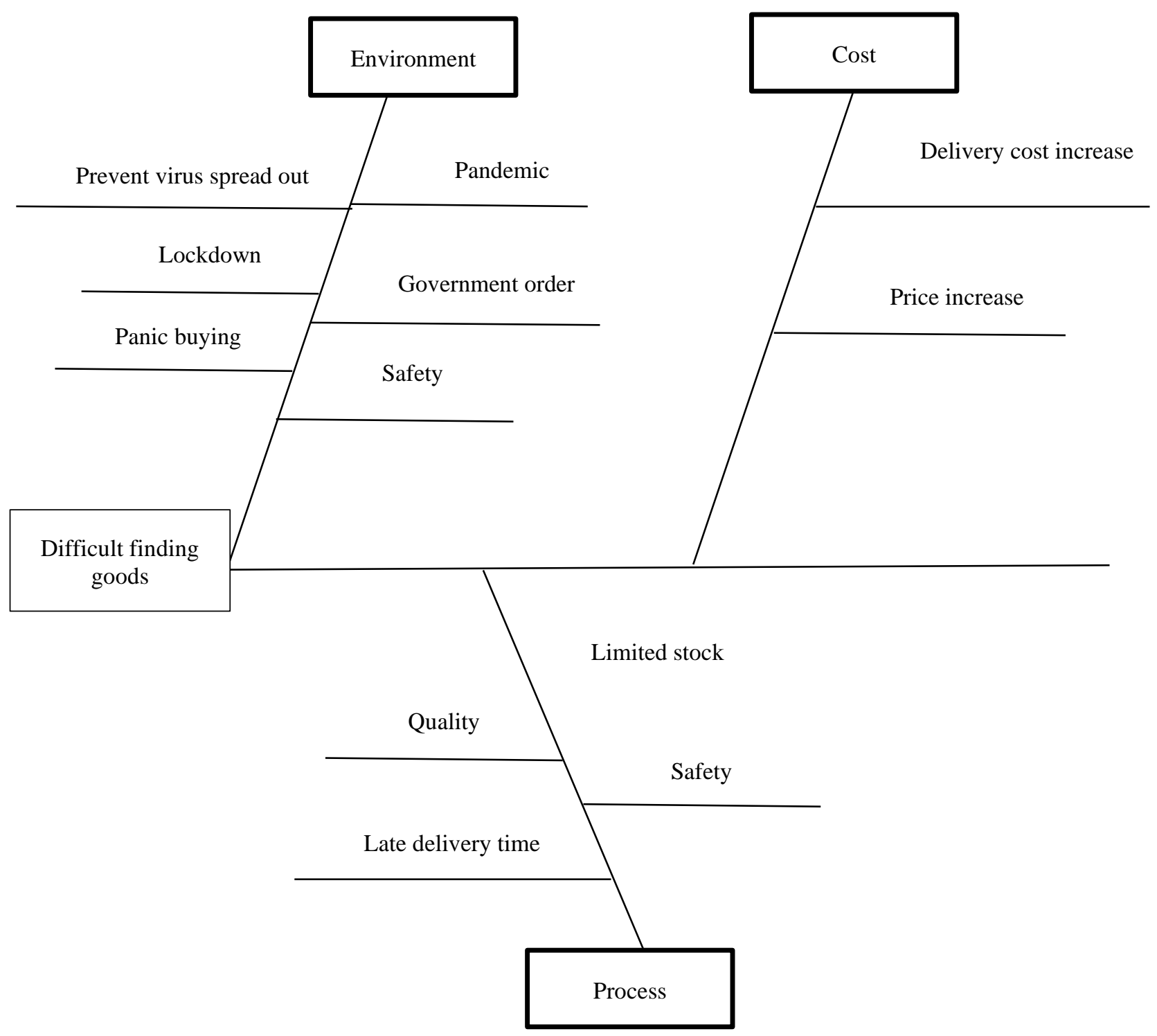

Figure 8: Ishikawa Diagram

Refer to the Ishikawa diagram; we can infer that the key cause that leads to difficulties in locating the goods is the current Pandemic. With all the lock down and the new norm because of the covid-19, it does make it difficult to find a good quality product with a very low price.

In the other side, there are also some difficulties in the management of the workers in the company. Being in the oil and gas business with a long term contract with the client, adding the right staff/workers at the right time will increase the productivity and quality of the company. In the procurement department, in spite of their busy work structure, only 2 employees are available. Therefore a tree diagram was implemented to describe the root cause and the analysis of the labour difficulties. The Tree diagram is in Figure 9. 


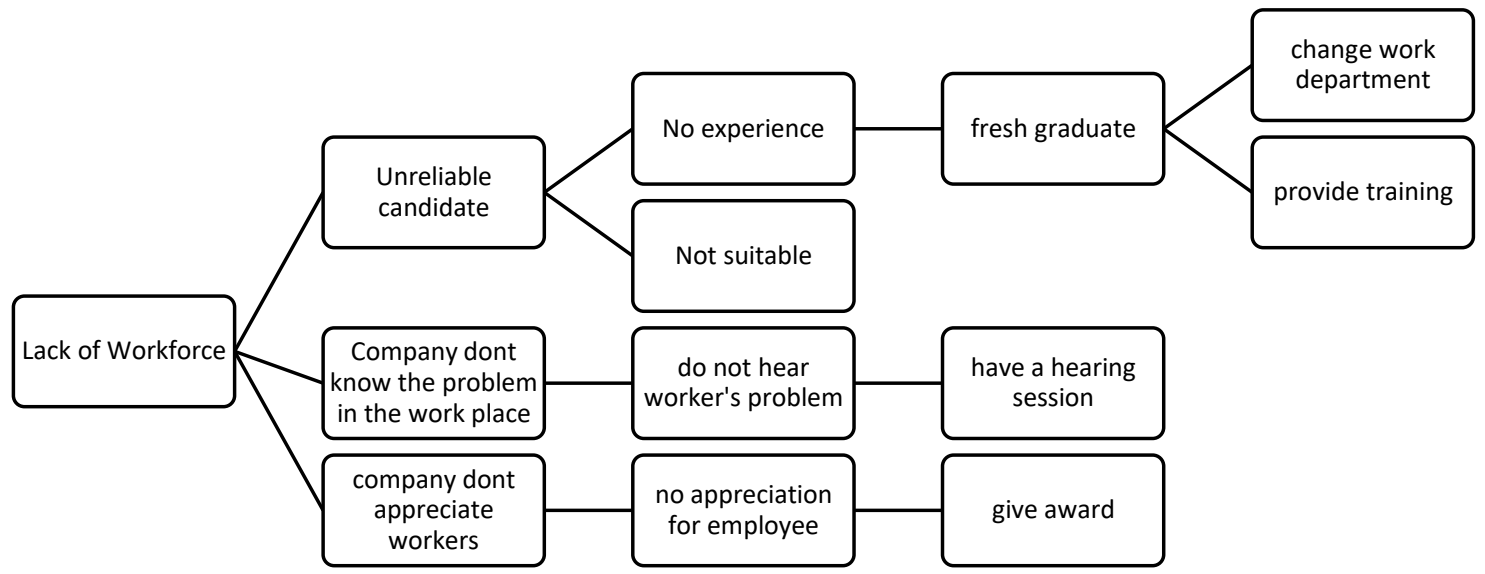

Figure 9: Tree Diagram for Workforce management

Figure 9 indicates that there are a range of root causes in the company's workforce management that indicate a shift in order to increase the efficiency of the company. Recruiting a non-experienced applicant may be a smart step by giving them a probationary period or even giving them training to train them in the business. Nobody manages to be a professional just by started their first move. Otherwise the organisation might also try to rearrange the existing employees' job department. For example, the organisation might arrange for a worker from Department A to work permanently in Department B. This could save the company's time and expense in locating and hiring new employees.

Adding to the current Pandemic issues, it is certain that the company might be a little distracted by all the new style of work. With only 2 members in the Procurement department, the employee may have been burdened. Based on the interviewee that is currently worked as the Technical Assistant in the company, she need to do 3 people's work as they had short number of workers in the company.Plus, they sometimes need to work overtime for at least two months straight for the workpack compilation of preparation campaign. Thus,it is much more flexible if the organisation is willing to try to assign workers from another department to work permanently in a department where there is a shortage of employees. Otherwise, company could also provide training for the potential current or new employees before permanently accepting them in the company or new department.

Besides, a hearing session will be a great catch for the organisation to take good care of the worker's internal thinking and to create a harmonious working atmosphere during this time of period. In addition, giving awards and appreciation to the employee can make it easier for employees to be more energetic in working in the business.

\section{SOCIAL NETWORK ANALYSIS}

This approach is intended to define organisational efficiency of the company. In this method, we may examine how each group in the organisation contributes to the decision-making process for the company. With this study, we could also analyse the movement of data inside the organisation. The analysis is carried out by examining the social network of the company's workers and identifying 3 centrality of the social network; Degree of centrality, Betweeness centrality and also Closeness centrality. The big red circle shown in the figures below represent the department or entity in the organisation, while the arrows indicate the movement of data between the company; moving in arrow means the data that is obtained from another person and moving out arrow means the data that needs to be moved to another person. The arrow also provide the type of data that are being transfer to each deparment or entity. 


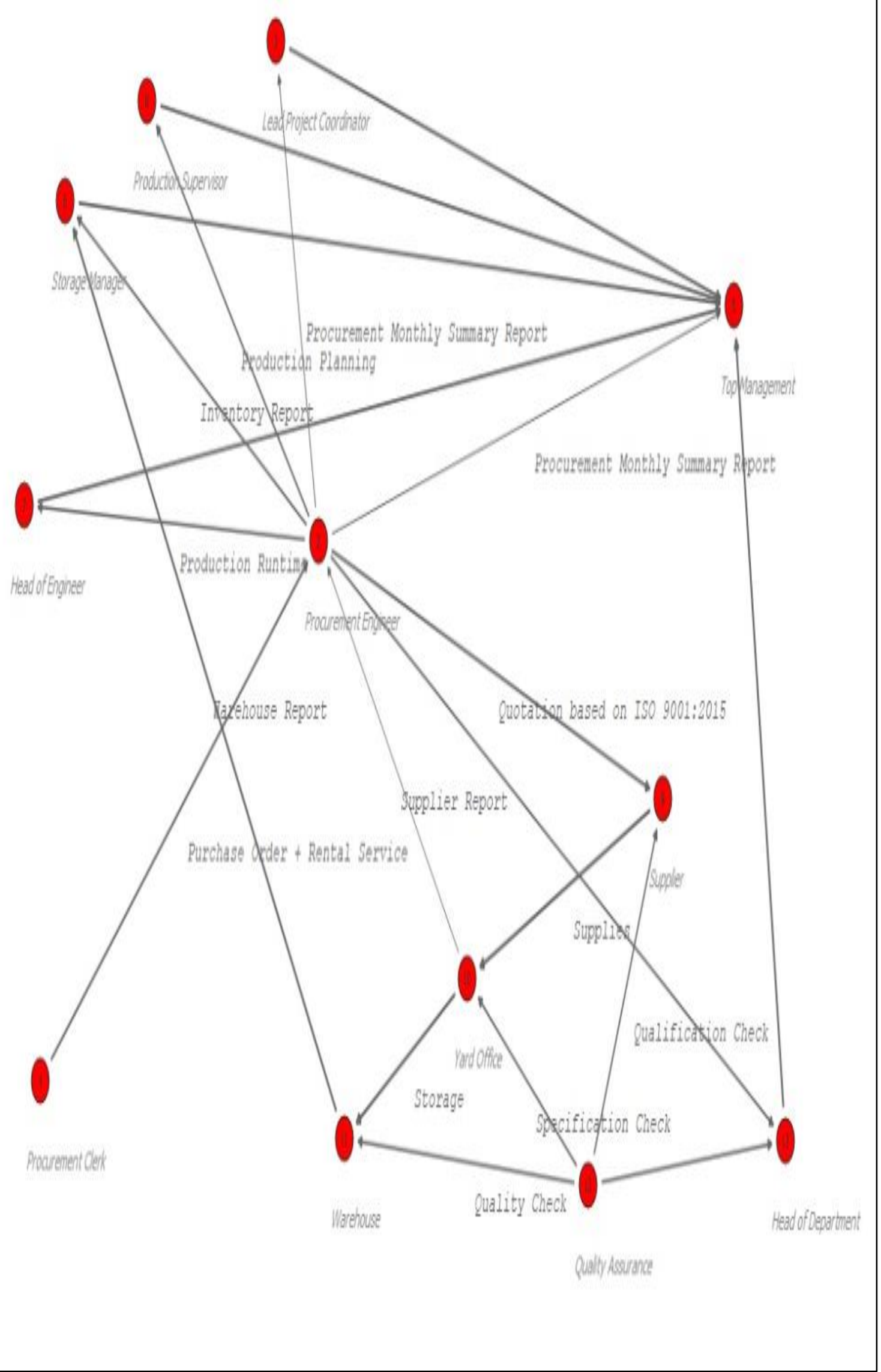

Figure 10: Procurement Engineer's social network

Figure 10 indicates that the company's Procurement Engineer is a middle person in the social network and that the Procurement Engineer still has to deal with top management. However, there could be redundancy, since many reports need to be submitted to many different departments for many other information. 


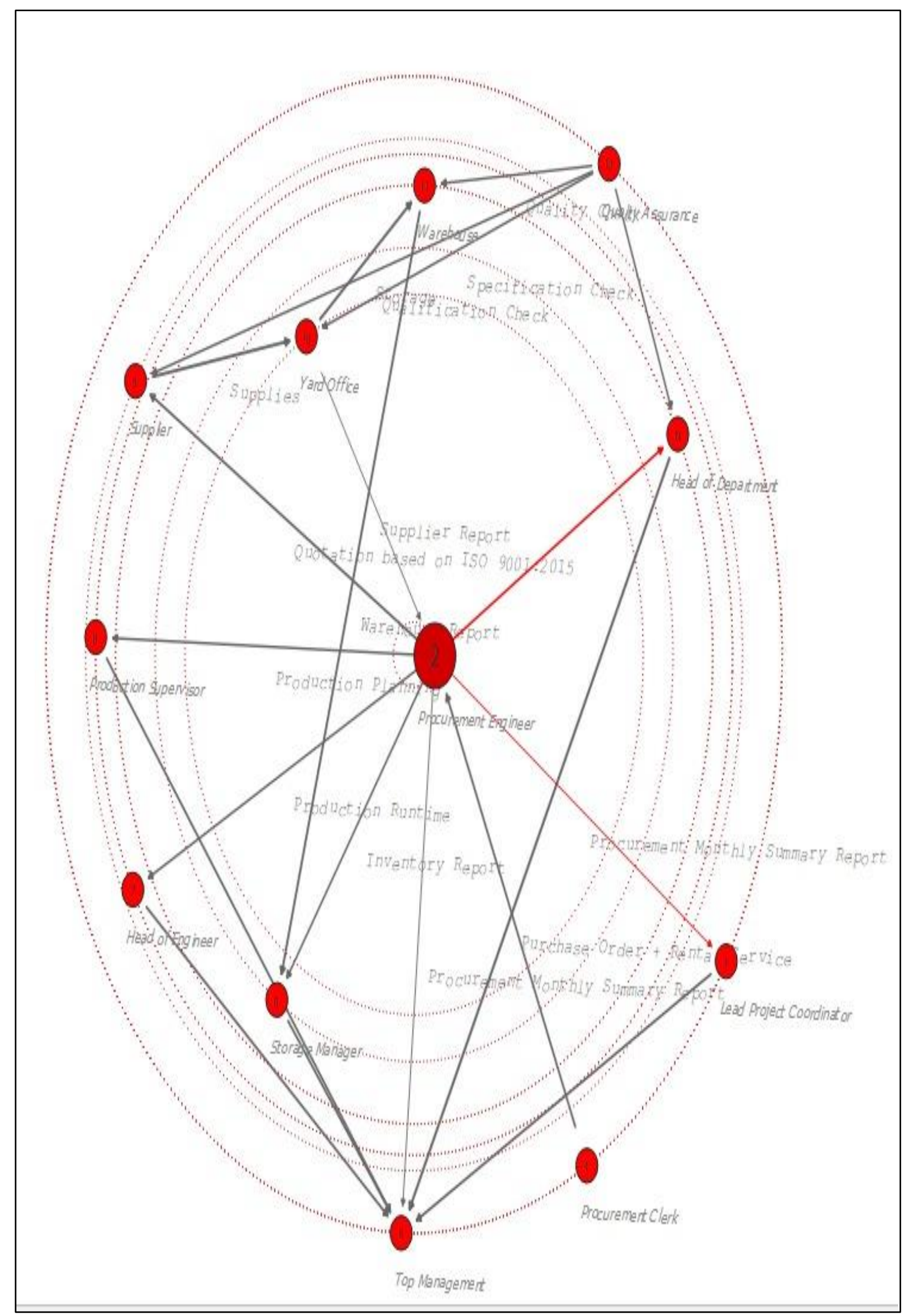

Figure 11: Social network's betweneess degree

The betweeness degree is often used to find the person who influences the social network of the organization and it calculates the number of times a node lies on the shortest path between other nodes. The Procurement Engineer's node is the middle of all the nodes in the social network from the figure 11 illustration, and has the shortest way to transfer data to the Top Management (Head of Department and the Lead Project Coordinator). 


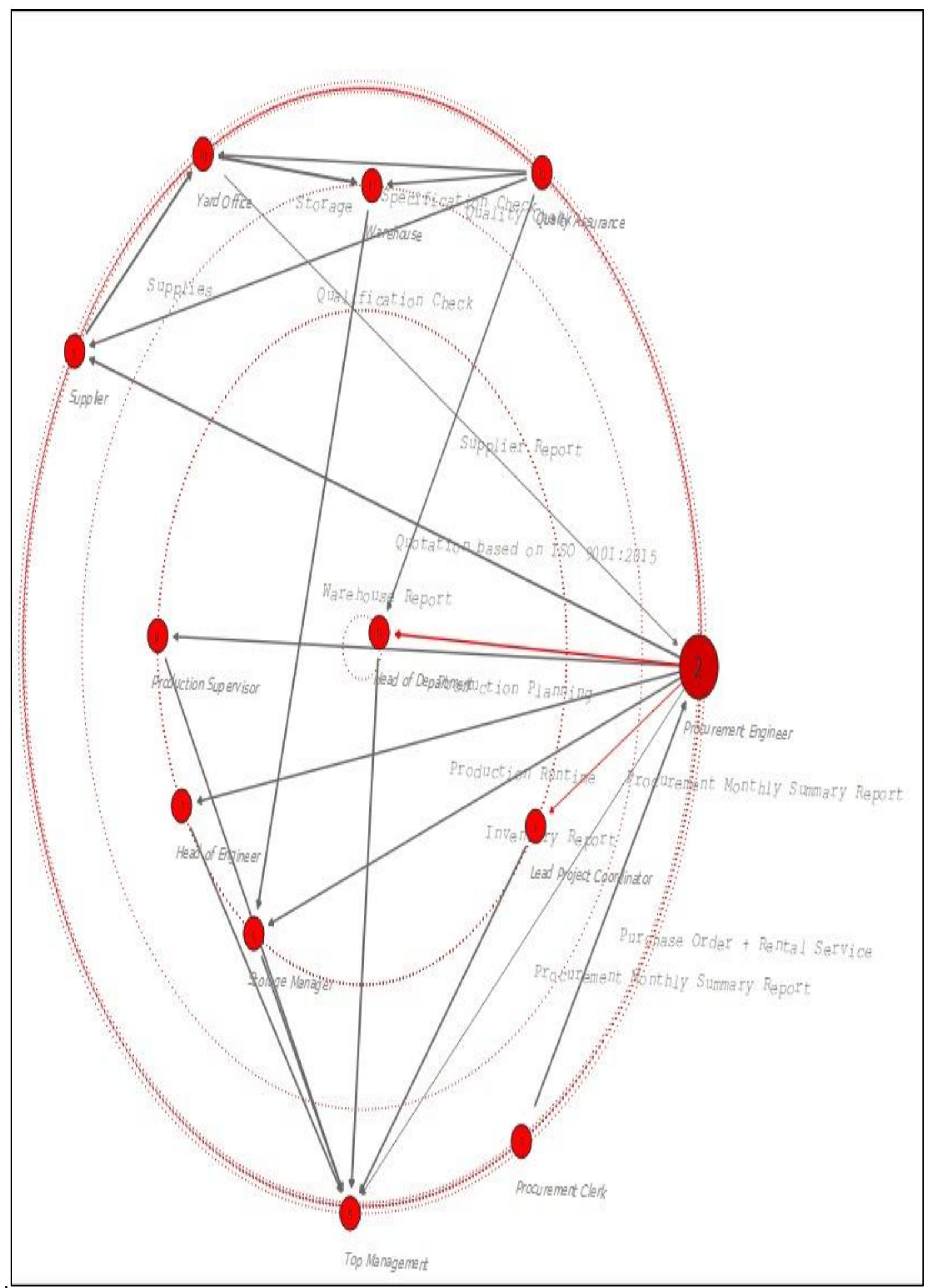

Figure 12: Closeness Degree in Social Network.

The Centrality of Closeness is used to find the people who are better positioned to control the company's whole network. This illustrates which nodes between all the nodes would have the shortest route.

In Figure 12, the degree of closeness indicates that the company procurement engineer has the highest circle in the network, implying that it has the shortest path based on the number of the shortest paths in the whole network. Plus, there was also a short road for the Procurement Engineers to transfer data to the Top Management. 


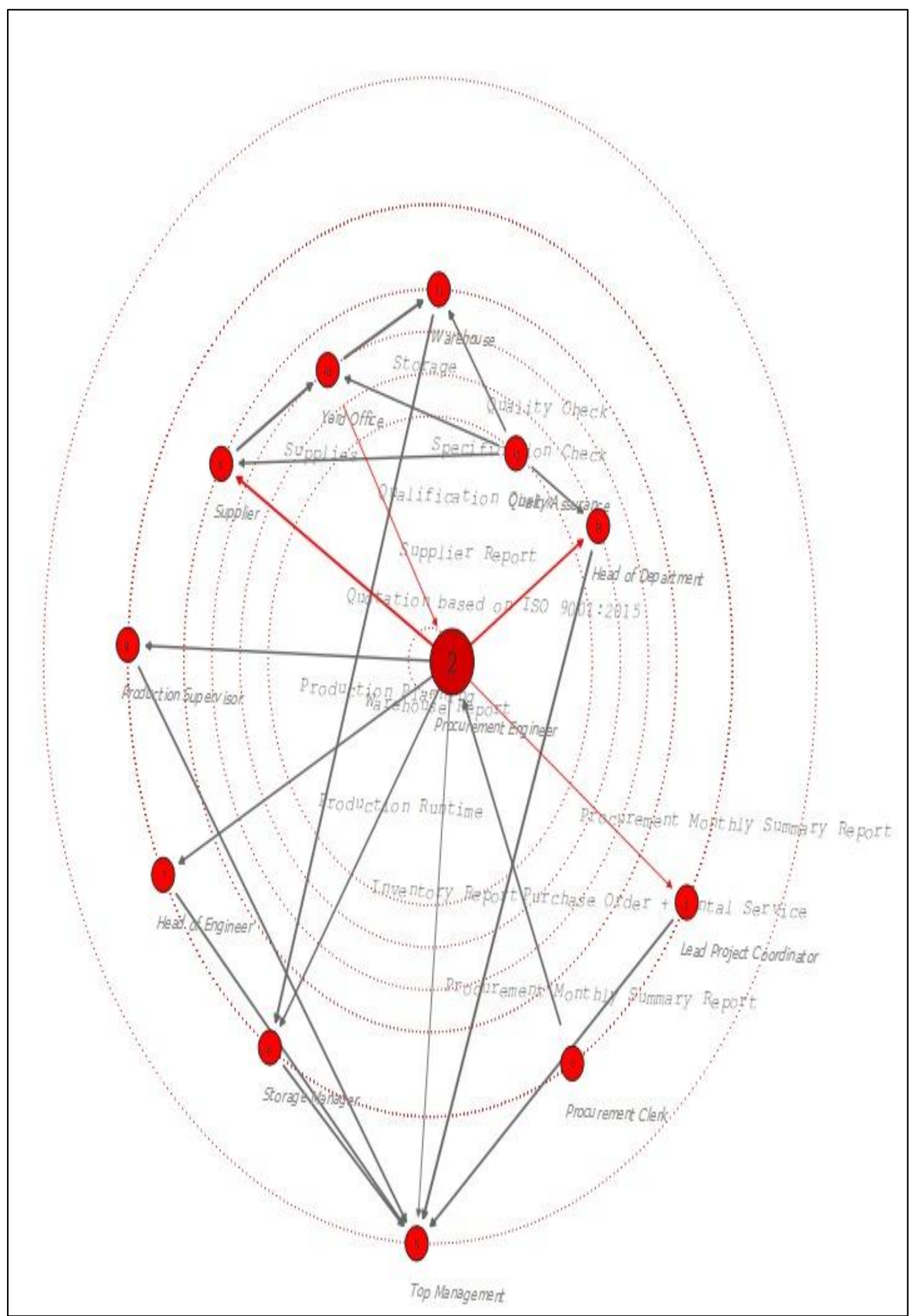

Figure 13: Social Network Centrality Degree

The Centrality Degree indicates the nodes with the largest number of network ties and contains much of the other individuals' information. Figure 13 then reveals that the Procurement Engineer is the main player with the largest number of ties in the center of the circle and is also a significant person in the process close to the centre, which may have a big impact on decision-making if the Procurement Engineer makes any mistakes. 


\section{ERP SYSTEM AS A SOLUTION}

The ERP system is well known for its ability to store and attribute data within the organisation, this will help the company enhance its efficiency and could also minimise its 7 waste in lean management. The quality of the company's operating performance or supply chain performance is not attainable due to duplication of reporting and chain of command and is thus recommended for lean management practises. The growing quantity of data gathered on social networks or based on different analytics requires device compatibility and the ability to store and process it in real time as well. As part of the regular kit, ERP systems will continue to provide robust solutions and on the other hand, focus will be put on their versatility and responsiveness to various organizational frameworks (Westerman \& Bonnet, 2019).

As far as the operating efficiency attribute is concerned, the ERP framework is more environmentally friendly as it will have cost-effectiveness and also contribute to modern technologies and would not affect the environment.

In addition, it is easier for the business group to move or provide data within the company as the ERP systems will provide a versatile response as the response is measured on the basis of product flexibility and delivery time. Various researchers concluded that ERP systems, adapted to the digital century, would enable access to information through different information systems, general information exchange and collaboration with other application systems, and modern business kit solutions (Williams and Schubert, 2018 ; Temel \& Ayaz, 2019 ; Strutynska et al., 2019; Sotnyk et al., 2020). Such incorporation will facilitate the development of a digital management tool that will be more responsive to the needs of the enterprise and will allow for a detailed adaptation of business activities and better integration of information and processes (Sotnyk et al., 2020).

Based on studies by Menshikova et al. (2019), companies are accelerating their innovation cycles and making supply chains more flexible. This was also discussed in the analysis of Yang and Su (2011), which demonstrates the advantages of providing an Enterprise Resource System (ERP) system on the company and the effects of this enterprise system on other areas or IT systems, such as the Supply Chain Management (SCM) system that is integrated with it. Supporting the role of ERP in controlling financial capital, developing new principles and new business models (Križanić, Šestanj-Perić \& Tomičić-Pupek, 2019). Table 2 showed further ERP advantages in enhancing the supply chain efficiency of the business (Ali et al., 2015).

Table 2: ERP benefits in improving the Supply Chain Management

\begin{tabular}{l} 
Enterprise Resource Planning (ERP) Benefits \\
\hline Operational Benefits \\
Operational \\
$\begin{array}{l}\text { The organizational advantages are that of the automation } \\
\text { of cross-functional systems. }\end{array}$
\end{tabular}

of cross-functional systems.

\section{Internal business process perspective}

The internal business process begins with the issuance of a customer order and concludes with the distribution to the customer of the goods or service, representing how efficiently inventory and labour capital are used to supply service, and this involves enhancing production process performance, improving inventory control, increasing distribution efficiency, increasing flexibility, improving support for the information system, and improving the creation of new goods.

\section{External business process perspective}

The increased outsourcing of production firms leads to a greater reliance on the external market process, and several SCM strategies are produced to facilitate this, representing wider business initiatives used to boost customer satisfaction, focused on the logic that core consumers are drawn and maintained by superior service.

\section{Customer service perspective}

Tactical benefits Managerial

The management group involves advantages resulting from the use of data to help organize and handle manufacturing, personnel, inventory and physical capital, and from the financial performance analysis and tracking of goods, clients, market lines, and the geographical region.
The forms of value delivered to the consumer are defined by customer support. Although there are a range of unique customer service indicators, the report focuses on customer loyalty, product flexibility, product leadership, distribution speed and accuracy of order monitoring. 


\begin{tabular}{|l|l|}
\hline \multicolumn{1}{|c|}{ Enterprise Resource Planning (ERP) Benefits } & \multicolumn{1}{c|}{ Supply Chain Management (SCM) } \\
\hline$\underline{\text { Strategic benefits }}$ & Cost management \\
$\begin{array}{l}\text { The division of strategic benefits reflects on the benefits } \\
\text { that result from the capacity of the mechanism to } \\
\text { promote market development. }\end{array}$ & $\begin{array}{l}\text { Cost accounting reports on cost aspects of the functional } \\
\text { and logistics and supply chain and demonstrates how } \\
\text { effectively a business manages fixed assets and working } \\
\text { capital. }\end{array}$ \\
\hline $\begin{array}{l}\text { Organisational } \\
\begin{array}{l}\text { The division of organizational benefits captures the } \\
\text { benefits resulting from company learning facilitation, } \\
\text { workforce empowerment, and improved productivity and } \\
\text { happiness of workers. }\end{array}\end{array}$ \\
\hline
\end{tabular}

Thus, by having all the operational performing attributes, this shows that ERP systems could help the HHA Associates Sdn. Bhd. to improve their company's green supply chain operational performance and solving their company's management problems.

In addition, the organisation could reduce some of the duties of the Procurement Engineer by assigning some of the tasks of the Procurement Engineer to individuals with the least work to decrease the workload of the Procurement Engineer who could work more flexibly. In other benefit, this may also help the organisation minimise the expense of paying employees' salaries.

The handling of financial and operational activities is becoming a significant factor that can affect the sustainable growth of the business (Nor et al., 2020). While the priority of short-term cash flow is paramount, it is very important to remain focused on the longer term. Companies that concentrate solely on the short term will forego the ability to develop the necessary capacity for the future under the new set of constraints. This needs an affordable investment in the creation of mineral reserves, the development of skills and technology and innovation, particularly in terms of moving towards a globally competitive, digital environment that delivers real value (Macfarlane, 2020). It is therefore necessary for the company to be more specific in any decision to purchase or any operation involving financial matters.

\section{CONCLUSION}

With all the analysis that was made, we may conclude that there was no significant improvement in any process in the business before and during Covid-19. The only thing that is different in the business is the length of a certain phase in the company. In addition the company should not depend on the Procurement Engineer as a whole, otherwise it will put more burdens on the person; in reality, there is only one Procurement Engineer in the company. On the other hand, it is also challenging for the assistant technician, as she was responsible for three tasks due to lack of workers.

In order to boost the company's green supply chain operational performance, it is recommended that the company implement Enterprise Resource Planning (ERP) programs. By introducing the system, the business will minimize operational costs, which are one of the attributes of green supply chain operating performance, through eliminating waste inside an organization that is unprofitable, such as time wasting, inventory wasting in need of physical space for data storage, travel wasting due to the need to pass about for data transfer and even waiting in response from another department.

Moreover, by introducing the Enterprise Resource Planning (ERP) programs in the business, this will demonstrate that the company is flexible enough to make a change in the management of the supply chain process due to the actual scenario, which is in critical position and constraint. ERP systems also have green supply chain operating performance attributes that are responsiveness as the system will provide the information required without the workers needing to spend time searching for information from other employees. Moreover, because the systems are a technological solution, they may be categorized as a more environmentally friendly method. Before the Enterprise Resource Planning (ERP) programs are introduced, the use of paper is very frequent in order to capture documents, so since the information is all in the system, the use of paper will be reduced, which could benefit the ecosystem better.

Thus, with all the benefits listed, we can infer that the Enterprise Resource Planning (ERP) system could enable companies in Malaysia to improve their green supply chain operational management, especially during the Covid-19 pandemic. Finally, this study assume that the preparation of the company to cope with such emergency scenarios is too slow and that the phase and development of the company can worsen if the pandemic lasts longer. Consideration should be extended to means of increasing the company's profits after the pandemic. 


\section{REFERENCES}

Abdullah, J. M., Ismail, W. F. N. M. W., Mohamad, I., Ab Razak, A., Harun, A., Musa, K. I., \& Lee, Y. Y. (2020). A Critical Appraisal of COVID-19 in Malaysia and Beyond. Mal J Med Sci, 27(2), 1.

Toda, A. A. (2020). Susceptible-Infected-Recovered (SIR) dynamics of COVID-19 and economic impact. Cornell University. Retrieved from https://arxiv.org/pdf/2003.11221.pdf

Badkar, M., \& Greeley, B. (2020). New data shows vast scale of US economic breakdown.Financial Times April 15, 2020.

Fabeil, Noor \& Pazim, Khairul \& Langgat, Juliana. (2020). The Impact of Covid-19 Pandemic Crisis on MicroEnterprises: Entrepreneurs' Perspective on Business Continuity and Recovery Strategy. 3. 837-844. 10.31014/aior.1992.03.02.241.

Ghani, F. A. (2020). Impak psikologi akibat wabak Covid-19, Astro Awani, 14 Mac 2020, retrieved from http://www.astroawani.com/berita-malaysia/impak-psikologi-akibat-wabak-covid-19-233648

Karabag, S. F. (2020). An unprecedented global crisis! the global, regional, national, political, economic and commercial impact of the coronavirus pandemic, Journal of Applied Economics and Business Research,10(1), 1-6.

World Health Organisation (2020). Coronavirus disease (Covid-2019) situation reports, retrieved from https://www.who.int/emergencies/diseases/novel-coronavirus-2019/situation-reports/

Fu, M., and H. Shen. 2020. COVID-19 and corporate performance in the energy industry -Energy Research Letters Moderating effect of goodwill impairment.1 (1):12967. doi:10.46557/001c.12967

Shen H.Y., Man Z., Wang M.S., Jun Z., Guo Z.L., (2020) Does Teacher-Turned Businessmen Curb Accrual-Based Earning Management and Real Activity Manipulation. Emerging Markets Finance and Trade 0:0, 1-13.

Mohamed S., Abdul M.,(2020, May 4). The financial impact of Covid-19. Retrieved from https://www2.deloitte.com/my/en/pages/financial-advisory/articles/financial-impact-of-covid-19.html

Flanders investment and trade.(2020, Nov 12). CORONA VIRUS-the situation in Malaysia. Retrieved from https://www.flandersinvestmentandtrade.com/export/nieuws/corona-virus-\%E2\%80\%93-situation-malaysia

Macfarlane, A.S.. (2020). The first 100 days after lockdown. Journal of the Southern African Institute of Mining and Metallurgy, 120(4), iv-vi. Retrieved November 17, 2020, from http://www.scielo.org.za/scielo.php?script=sci_arttext\&pid=S2225-62532020000400001\&lng=en\&tlng=en.

Nor.F.M., Ramli.N.A., Marzuki.A., \& Rahim.N., (2020). “Corporate Sustainable Growth Rate: The potential Impact of Covid-19 on Malaysian Companies", The Journal of Muamalat and Islamic Finance Research. 17(2020).25-38. ISSN:1823-0752

Kumar.A., Luthra.S., Mangla.S.K.,\& Kazaconglu.Y., (2020). "Covid-19 Impact on Sustainable Production And Operation Management", Sustainable Operations and Computers,(2020) 1-7

Voon.Z.Y.,(2020) “Struggle of Malaysian SME's During The Covid-19 Pandemic". Strategie Institute for Asia Pacific

Bhatia.M.,(2018, June 11). A Complete Guide to Quantitative Research Guideline.Human of Data. Retrieved from https://humansofdata.atlan.com/2018/06/quantitative-research-methods/

Snyder.H.,(2019). "Literature Review as a research methodology: An overview and guidelines”,Journal of Business Research. 104(2019) 333-339.

Igwenagu.C.,(2016, April). "Fundamenatals of research methodology and data collection" :ResearchGate. https://www.researchgate.net/publication/303381524

Paulraj, A., Chen, I. J., \& Blome, C. (2017). Motives and performance outcomes of sustainable supply chain management practices: A multi-theoretical perspective. Journal of Business Ethics, 145(2),239-258.

Naway.F.A.\& Rahmat.A.,(2019). “The mediating role of technology and logistic integration in the relationship between supply chain capability and supply chain operational performance”. Uncertain Supply Chain Management.7 (2019). 553-566.

Alzoubi.H.M.,\& Yanamandra.R.,(2020). "Investigating the mediating role of information sharing strategy on agile supply chain”.Uncertain Supply Chain Management.8 (2020). 273-284

Fang, C., Zhang, J., 2018. Performance of green supply chain management: a systematic review and meta analysis. J. Clean. Prod. 183, 1064-1081.

Kumar.G.,Subramaniam.N.,\&Arputham.R.M.,(2018). "Missing link between sustainability collaborative strategy and supply chain performance: Role of dynamic capability”.International Journal of Production Economics,203 (2018), 96-109

Brick, I.E., Fung, W.K.,(1984). The effect of taxes on the trade credit decision. Financ.Manag. 13, 24-30.

Dye, C.-Y., Yang, C.-T.,( 2015). Sustainable trade credit and replenishment decisions with credit-linked demand under carbon emission constraints. Eur. J. Oper. Res. 244,187-200.

Gong, Y., Jia, F., Brown, S., Koh, L.,(2018). Supply chain learning of sustainability in multitier supply chains: a resource orchestration perspective. Int. J. Oper. Prod. Manag. 38,1061-1090.

Caniato, F., Gelsomino, L.M., Perego, A., Ronchi, S.,( 2016). Does finance solve the supply chain financing problem? Supply Chain Manag.: Int. J. 21, 534-549.

Wang.Z.Q.,Wang.Q.,Lain.Y.,\& Liang C.J.,(2020). “Drivers and outcomes of supply chain finance adoption: An empirical investigation in China". International Journal of Production Economics 220 (2020) 107453

Centobelli, P., Cerchione, R., Esposito, E.,(2017). Developing the WH2 framework for environmental sustainability in logistics service providers: a taxonomy of green initiatives. J. Clean. Prod. 165, 1063-1077. 
Evangelista, P., Colicchia, C., Creazza, A.,(2017). Is environmental sustainability a strategic priority for logistics service providers? J. Environ. Manag. 198 (1), 356-362.

Javaid.T.,\& Siddiqui.D.A.,(2018). "Supply Chain Responsiveness and Supply Chain Performance: The Role of Supply Chain Risk Management". SSRN: 3285077. https://ssrn.com/abstract=3285077

Jiang, W., Sha, E. H.-M., Zhuge, Q., \& Wu, L. (2017). Efficient assignment algorithms to,minimize operation cost for supply chain networks in agile manufacturing. Computers\& Industrial Engineering, 108, $225-239$. https://doi.org/10.1016/j.cie.2017.04.014.

Ramezankhani.M.J., Torabi.S.A., \& Vahidi.F.,(2018). "Supply chain performance measurement and evaluation: A mixed sustainability and resilience approach". Computers \& Industrial Engineering 126 (2018) 531-548

Upton, D.M. (1994). The management of manufacturing flexibility.California Management Review, 36(2), $72-89$.

Muntaka.S.A., Haruna.A.,Mensah.K.H., (2017). “ Supply Chain Integration and Flexibility and Its Impact on Business Performance".International Journal of Business and Management. 12(4). ISSN 1833-3850. E-ISSN 1833-8119

Adivar B, Hüseyinoğlu IÖY, Christopher M. A quantitative performance management framework for assessing omnichannel retail supply chains. J Retail Consum Serv 2019;48:257-69. doi:10.1016/J.JRETCONSER.2019.02.024.

Farsi.M., Bailly.A.,Bodin., Penella.V.,Pinault.L.P.,Ngia E.T.T.,Sibson.J., \& Erkoyuncu.J.A., (2019). “An Optimisation Framework for Improving Supply Chain Performance: Case study of a bespoke service provider". Procedia Manufacturing,49 (2020), 185-192.

Choi.T.M., \& Guo.S.,(2017). "Responsive supply in fashion mass customisation systems with consumer returns". International Journal of Production Research; 56(10). 3409-3422. https://doi.org/10.1080/00207543.2017.1292065

Kozienkova, I., Palmatier, R.W., Fang, E., Xiao, B. and Huang, M. (2017), “Online relationship formation”, Journal of Marketing, 81(3), 21-40.

Kregar, T. and Antoncic, B. (2016), “The relationship between the entrepreneur's personal network multiplexity and firm growth", The Economic Research-Ekonomska Istrazivanja,29 (1),1126-1135.

Scuotto, V., Del Giudice, M., Bresciani, S. and Meissner, D. (2017), "Knowledge-driven preferences in informal inbound open innovation modes. An explorative view on small to medium enterprises", Journal of Knowledge Management, 21( 3),640-655.

Akintoye, A. (2015). Developing Theoretical and Conceptual Frameworks. Jedm.oauife.edu.ng >uploads $>2017 / 03 / 07$ (accessed 2017 February 22)

Ravitch, S. M. \& Carl, N. M. (2016). Qualitative Research: Bridging the Conceptual,Theoretical and Methodological. Los Angeles, U.S.A.: SAGE Publications, Inc.

Crossley, N., \& Edwards, G. (2016). Cases, mechanisms and the real: The theory and methodology of mixed-method social network analysis. Sociological Research Online, 21(2),1-15. https://doi.org/10.5153/sro.3920

Hollstein, B. (2014). Mixed methods social networks research: An introduction. In S.Domínguez \& B. Hollstein (Eds.), Mixed methods social networks research: Design and applications (pp. 3-34). Cambridge University Press.

Moolenaar, N. M. (2012). A social network perspective on teacher collaboration in schools: Theory, methodology, and applications. American Journal of Education, 119(1), 7-39. https://doi.org/10.1086/667715

Sweet, T. M. (2016). Social network methods for the educational and psychological sciences. Educational Psychologist, 51(3-4), 381-394. https://doi.org/10.1080/00461520.2016.1208093

Froehlich.D.E.,Waes.S.V.,\& Schafer.H.,(2020)““Linking Quantitative and Qualitative Network Approaches: A Review of Mixed Methods Social Network Analysis in Education Research".44.244-268.DOI: 10.3102/0091732X20903311

Partelow.S., Nelson.K.,(2020). "Social networks, collective action and the evolution of governance for sustainable tourism on the Gili Islands, Indonesia”. Marine Policy $112 \quad$ (2020) 103220. https://doi.org/10.1016/j.marpol.2018.08.004

Li, K., F. Mai, R. Shen, and X. Yan, 2020. Measuring corporate culture using machine learning, Review of Financial Studies forthcoming

De Nooy, W.; Mrvar, A.; Batagelj, V. Exploratory Social Network Analysis with Pajek; Cambridge University Press: Cambridge, UK, 2018.

Loon.L.K.,Nawanir.G.,Bakar. Z.A.,Hanaysha.J., (2019) "Strengthening Supply Chain Operational Performance through Relational and Organizational Culture Capabilities”. Int. J Sup. Chain. Mgt. 8(4).90-98

Saudi M.H.M., Juniati S., Kozicka K., Razimi M.S.A., (2019). "Influence of lean practices on supply chain performance”. Polish journal of management studies. 19(1). 353-363. DOI: 10.17512/pjms.2019.19.1.27

Heizer, J., \& Render. B., (2013). "Principles of Operations Management”. Pearson Education, Limited. Retrieved from https://books.google.com.my/books?id=LBqUmAEACAAJ

Kwarteng, A., \& Aveh, F. (2018). "Empirical examination of organizational culture on accounting information system and corporate performance: Evidence from a developing country perspective". Meditari Accountancy Research,26(4), 675-698.

Truong.H.Q.,Sameiro M.,\& Fernandes A. C.,(2017).“Supply chain management practices and firms' operational performance,"International Journal of Quality \& Reliability Management,34(2), 176-193.

Modgil.S.,\& Sharma.S.,(2016).“Total productive maintenance, total quality management and operational performance,” Journal of Quality in Maintenance Engineering, 22(4),353-377.

Marodin.G.A.,(2019)“Lean production and operational performance in the Brazilian automotive supply chain," Total Quality Management \& Business Excellence,30(3-4), 370-385. 
Camacho.D.,Lledot.A.P.,Orgaz.G.B., \& Pardo.A.G.,(2020). "The four dimensions of social network analysis: an overview of research method, applications, and software tools". Information Fusion, (63), 88-120. www.elsevier.com/locate/inffus

Jafari, A.A., \& Nair, S.S. (2018). "ERP Implementation in the Oil and Gas Sector: A Case Study in Sultanate of Oman”. 2018 7th International Conference on Reliability, Infocom Technologies and Optimization (Trends and Future Directions) (ICRITO), 848-854.

Hadidi, M., Hussein,Y.S., Hadidi, S.(2019).”Compariosn between Cloud ERP and Traditional ERP”;Journal of Critical Review.7(3), 140-142

Parmar, A.,(2019,May,20)."12 Types of ERP modules and their uses".Software Suggest. Retrieved from https://www.softwaresuggest.com/blog/erp-system-modules/

Almuhayfith.S., \& Shaiti. H., (2020). “The Impact of Enterprise Resource Planning on Business Performance: With the Discussion on Its Relationship with Open Innovation”. J.Open Innov. Technol. Mark. Complex. 87(6) . doi:10.3390/joitmc6030087

Lisa.S., (2020). “6 Key Phases of an ERP Implementation Plan”. Oracle Netsuite. Retrieved from https://www.netsuite.com/portal/resource/articles/erp/erp-implementation-phases.shtml

Westerman, G. and Bonnet, D. (2019). Revamping Your Business Through Digital Transformation. MIT Sloan Management Review, pp. 1-5. (2015).

Williams, S.P. and Schubert, P. (2018). Designs for the Digital Workplace. Procedia Computer Science, Vol. 138, pp. 478-485.

Temel, A. and Ayaz, M. (2019). Digital Transformation Design of Banbury Mixing Unit in Tire Manufacturing. Proceedings of International Conference on Applied Automation and Industrial Diagnostics, US \& Canada: IEEE, pp. 1-6.

Strutynska, I., Kozbur, G., Dmytrotsa, L., Sorokivska, O. and Melnyk, L. (2019). Influence of Digital Technology on Roadmap Development for Digital Business Transformation. Proceedings of International Conference on Advanced Computer Information Technologies (ACIT), US \& Canada: IEEE, pp. 333-337.

Sotnyk, I., Zavrazhnyi, K., Kasianenko, V., Roubík, H. and Sidorov, H. (2020). Investment Management of Business Digital Innovations. Marketing and Management of Innovations, Vol. 1, pp. 95-109.

Menshikova, M.A., Piunova, Y.V. and Makhova, M.N. (2019). Digital Transformation in the Quality Management System. Proceedings of International Conference Quality Management, Transport and Information Security, Information Technologies (IT\&QM\&IS) 2019, US \& Canada: IEEE, pp. 42-46.

Križanić, S., Šestanj-Perić, T. and Tomičić-Pupek, K. (2019). The Changing Role of ERP and CRM in Digital Transformation. Proceedings of International Scientific Conference on Economic and Social Development 2019, Varazdin Development and Entrepreneurship Agency, Varazdin, Croatia / Megatrend University, Belgrade, Serbia / University North, Koprivnica, Croatia / Faculty of Management University of Warsaw, Warsaw, Poland / Faculty of Law, Economics and Social Sciences Sale - Mohammed V University in Rabat, Morocco, pp. 248-256.

Ali.T., Ra'Ed.M., \& Takwa.T., (2015). “Analysis of the Critical Success Factors for Enterprise Resource Planning Implementation from Stakeholders' Perspective: A Systematic Review” . International Business Research. 8(6). 2540. doi:10.5539/ibr.v8n4p25

Yang, C., \& Su, Y.F. (2011). The relationship between benefits of ERP systems implementation and its impacts on firm performance of SCM. Journal of Enterprise Information Management, 22(6), 722752. http://dx.doi.org/10.1108/17410390910999602

\section{CONFLICT OF INTEREST}

The author(s), as noted, certify that they have NO affiliations with or involvement in any organisation or agency with any financial interest (such as honoraria; educational grants; participation in speakers' bureaus; membership, jobs, consultancies, stock ownership, or other equity interest; and expert testimony or patent-licensing arrangements), or nonfinancial interest (such as personal or professional relationships, affiliations, expertise or beliefs) in the subject matter or materials addressed in this manuscript. 


\section{AUTHORS' BIOGRAPHY}

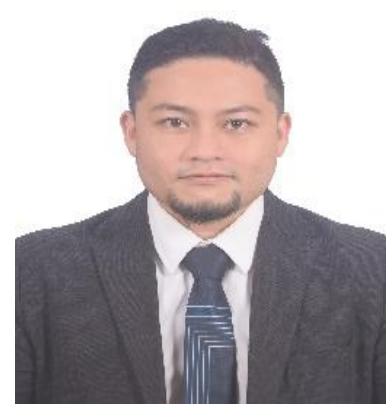

Muhammad Shabir Shaharudin received his Ph.D. from Universiti Malaysia Pahang and MBA in International Business from Universiti Sains Malaysia, while his bachelor's degree in international business was from Limkokwing University Malaysia. His interest area includes environmental supply chain management, supply chain management, ecoinnovation, international business, and social network analysis. He is currently the Assistant Managing Editor for the Journal of Governance and Integrity (JGI), Malaysia. He is the Associate Editor for the International Journal of Productivity Management and Assessment Technologies (IJPMAT), USA. Email: shabir@ump.edu.my

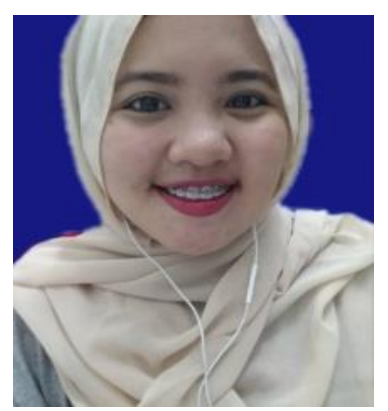

Syafiqa binti Suhaimi currently is a third year Bachelor degree in Business Engineering (Hons) student in Universiti Malaysia Pahang, Gambang, Pahang. Syafiqa's previous educational qualification is Diploma in E-commerce from Politeknik Sultan Haji Ahmad Shah, Kuantan, Pahang.

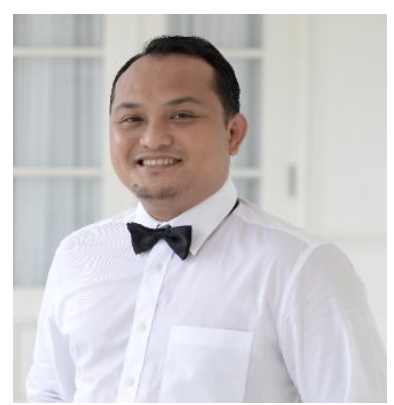

Yudi Fernando holds a Ph.D. and Associate Professor. He is the former Deputy Dean of Research and Postgraduate Studies at the Faculty of Industrial Management, Universiti Malaysia Pahang. He has experience working in the electronics industry for several years. His current research interests are sustainable supply chain management, halal logistics, blockchain technology, and service management. He is also a member of the Society of Logisticians, Malaysia/Pertubuhan Pakar Logistik Malaysia (LogM). Email: yudi@ump.edu.my 


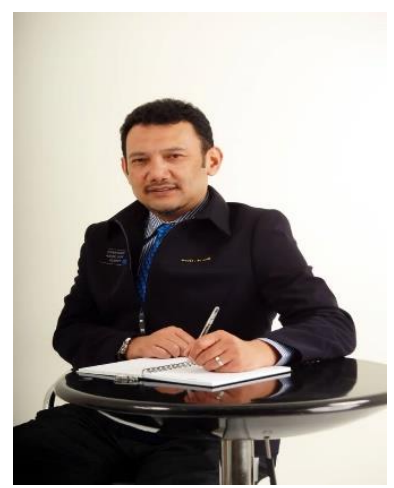

Wan Ahmad Fauzi was admitted as an advocate \& solicitor at the High Court of Malaya, Kuala Lumpur on 23 September 1996. He is also qualified as a Syar'ie counsel for the State of Terengganu and the Federal Territories. In 2012, he was listed in "The Book of Malaysia Leaders: Political, Government \& Corporate. He is currently the Director of The Institute of Civilization and Strategic Research, Malaysia. He once held a few prominent posts such as the Secretary of Terengganu Council of The Royal Court. At presence, he actively involves in NGOs. He obtained his PhD in constitutional law together with the certificates of Graduate on Time and Distinction PhD Thesis from the Law Faculty of The National University of Malaysia. Wan Ahmad Fauzi is the founder of Watan Jurisprudence. In recognizing his great contribution to our country, he was conferred a few Royal Awards such as PJN., DPNS., SMT. Email: wanfauzi@ump.edu.my

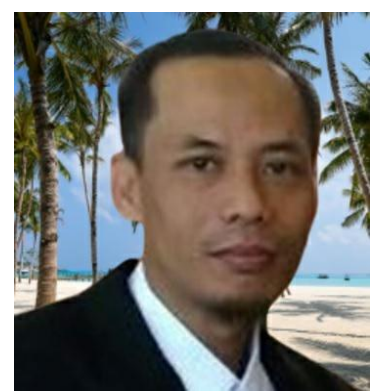

Suparman received his Ph.D from Yogyakarta State University Indonesia in education measurement. His bachelor degree is from Yogyakarta State University of Indonesia in Economic Education and a Postgraduate degree from Gadjah Mada University Yogyakarta Indonesia in Psychometry. He works as a lecturer who specializes in educational statistics, evaluation and measurement of education, and Developmental Psychology. Currently he is the Chair of the Senate at the Islamic College of the Syuhada Mosque in Yogyakarta (STAIMS), Indonesia. He is also an educational consultant at two institutions, namely the Bakti Insani Islamic First Middle School and the Muna Falih Islamic Boarding School. 